\author{
Visión Electrónica \\ Más que un estado sólido \\ https://doi.org/10.14483/issn.2248-4728
}

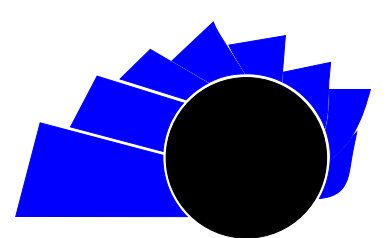

VISIÓN ELECTRÓNICA

\title{
Duty cycle and radiation estimates using maximum load transfer point for optimization of a 100KVA photovoltaic system
}

\author{
Estimaciones de ciclo de trabajo y radiación utilizando máximo punto de \\ transferencia de carga para la optimización de un sistema fotovoltaico de \\ $100 K V A$
}

\author{
Sergio Alejandro Terán-Rodríguez ${ }^{(\mathrm{D})}{ }^{1}$, Franklin Jonathan Rojas-Caicedo ${ }^{\left(D^{2}\right.}{ }_{2}$, \\ Esteban Mauricio Inga-Ortega ${ }^{(\mathbb{D}} 3$
}

INFORMACIÓN DEL ARTÍCULO

Historia del artículo:

Enviado: 20/01/2020

Recibido: 18/03/2020

Aceptado: 11/06/2020

\section{Keywords:}

Duty cycle

MPPT

Photovoltaic

Power

Radiation

Temperature

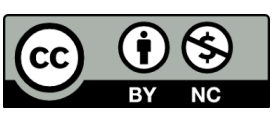

Palabras clave:

Duty cycle

MPPT

Fotovoltaico

Potencia

Radiación

Temperatura

\begin{abstract}
In this document, the variation of temperature and radiation in a $100 \mathrm{~kW}$ photovoltaic assembly is connected to a $25 \mathrm{kV}$ network through a DC-DC booster converter and a three-phase three- phase voltage source converter (VSC). Maximum power point tracking (MPPT) is implemented in the elevator converter using a Simulink $\mathbb{R}$ model that uses the technique of 'Incremental Conductance + Integral Regulator'. The switching duty cycle is optimized by an MPPT controller that uses the technique of 'Incremental Conductance + Integral Regulator'. This MPPT system automatically modifies the duty cycle to generate the voltage required to extract the maximum power.
\end{abstract}

\section{RESUMEN}

En este documento, se describen la variación de la temperatura y radiación en un conjunto fotovoltaico de $100 \mathrm{~kW}$ está conectado a una red de $25 \mathrm{kV}$ a través de un convertidor de refuerzo CC-CC y un convertidor de fuente de voltaje trifásico de tres niveles (VSC). El seguimiento del punto de máxima potencia (MPPT) se implementa en el convertidor elevador mediante un modelo Simulink@ que utiliza la técnica de 'Conductancia incremental + Regulador integral'. El ciclo de trabajo de conmutación está optimizado por un controlador MPPT que utiliza la técnica de 'Conductancia incremental + Regulador integral'. Este sistema MPPT varía automáticamente el ciclo de trabajo para generar el voltaje requerido para extraer la potencia máxima.

\footnotetext{
${ }^{1}$ BSc. (c) in Electric Engineering, Universidad Politécnica Salesiana, Ecuador. E-mail: teranrsergio.r@gmail.com

2 BSc. (c) in Electric Engineering, Universidad Politécnica Salesiana, Ecuador. E-mail: frojasc@est.ups.edu.ec

${ }^{3}$ BSc. in Electronic Engineering, Universidad Politécnica Salesiana, Ecuador. PhD in Telecommunication, Universidad Pontificia Bolivariana, Colombia.
} 


\section{Introduction}

The solar power generation system has advanced and been investigated in several countries around the world as a new high-tech energy species that is highly promising [1]. This type of energy will occupy a very important position in the energy system in the coming years.

The output characteristic of the photovoltaic matrix is not linear due to the conditions with which this type of energy is acquired and that it changes through the different light conditions and temperature of the environment in which it is found. Therefore, the output power will be greatly affected by this factor. To ensure and guarantee that this output power value in the photovoltaic array is the maximum, the maximum power point must be tracked and found in real time.

There are some methods which can track the maximum power point among which are: constant voltage monitoring method, disturbance and observation method, the incremental conductance method, etc. [2,3] Although the constant voltage monitoring method can be easily controlled, itdoes not take into account the influence of temperature on the open circuit voltage, that is, when the temperature changes in great magnitude, it will produce large deviations in the final value. On the other hand, the efficiency of the disturbance and observation method and the incremental conductance method are relatively high compared to the previous one, but in this case the step of the variation of the working relationship in the MPPT circuit of the two methods is a constant and this is a big problem, because it is difficult to choose the variation step of the working ratio. The purpose of this article is to find and determine the maximum point of disturbance through a relationship in the variables that appear in each case, in turn, it is also intended to find a mathematical model that allows finding new relationships depending on radiation and temperature in the same sector. The step of the variation of the working ratio for this case is variable since with it the maximum power point can be detected. When the output power is having large variations in its magnitude, it quickly seeks to track the maximum power point again, that is, it uses very small steps near the maximum power point. The purpose of this article is to find and determine the maximum point of disturbance through a relationship in the variables that appear in each case, in turn, it is also intended to find a mathematical model that allows finding new relationships depending on radiation and temperature in the same sector. The step of the variation of the working ratio for this case is variable since with it the maximum power point can be detected. When the output power is having large variations in its magnitude, it quickly seeks to track the maximum power point again, that is, it uses very small steps near the maximum power point. The purpose of this article is to find and determine the maximum point of disturbance through a relationship in the variables that appear in each case, in turn, it is also intended to find a mathematical model that allows finding new relationships depending on radiation and temperature in the same sector. The step of the variation of the working ratio for this case is variable since with it the maximum power point can be detected. When the output power is having large variations in its magnitude, it quickly seeks to track the maximumpower point again, that is, it uses very small steps near the maximum power point. It is also intended to find a mathematical model that allows finding new relationships based on radiation and temperature in the same sector. The step of the variation of the working ratio for this case is variable since with it the maximum power point can be detected. When the output power is having large variations in its magnitude, it quickly seeks to track the maximum power point again, that is, it uses very small steps near the maximum power point. It is also intended to find a mathematical model that allows finding new relationships based on radiation and temperature in the same sector. The step of the variation of the working ratio for this case is variable since with it the maximum power point can be detected. When the output power is having large variations in its magnitude, it quickly seeks to track the maximum power point again, that is, it uses very small steps near the maximum power point.

The idea of the constant voltage monitoring method is as follows: the voltage of the photovoltaic array at the point of maximum power is almost the same under a different lighting intensity according to the output characteristics of the photovoltaic array, when the temperature remains constant. Therefore, it can be thought that the maximum power points of a given photovoltaic array correspond to approximately the same voltage. If the output voltage is controlled with this voltage, the $\mathrm{PV}$ array is working at the point of maximum power $[4,5]$.

The constant voltage tracking method is easy to control and has high reliability and stability. But it does not take into account the influence of temperature on the photovoltaic matrix. In practice, the output voltage of the PV array will decrease with increasing temperature. Therefore, the constant voltage tracking method will produce big deviation and power loss, when the temperature change is big. Therefore, its control precision is poor and it does not have the ability to adapt itself. 
Figure 1: Representation of the model implementation.

\section{PANEL FOTOVOLTAICO}
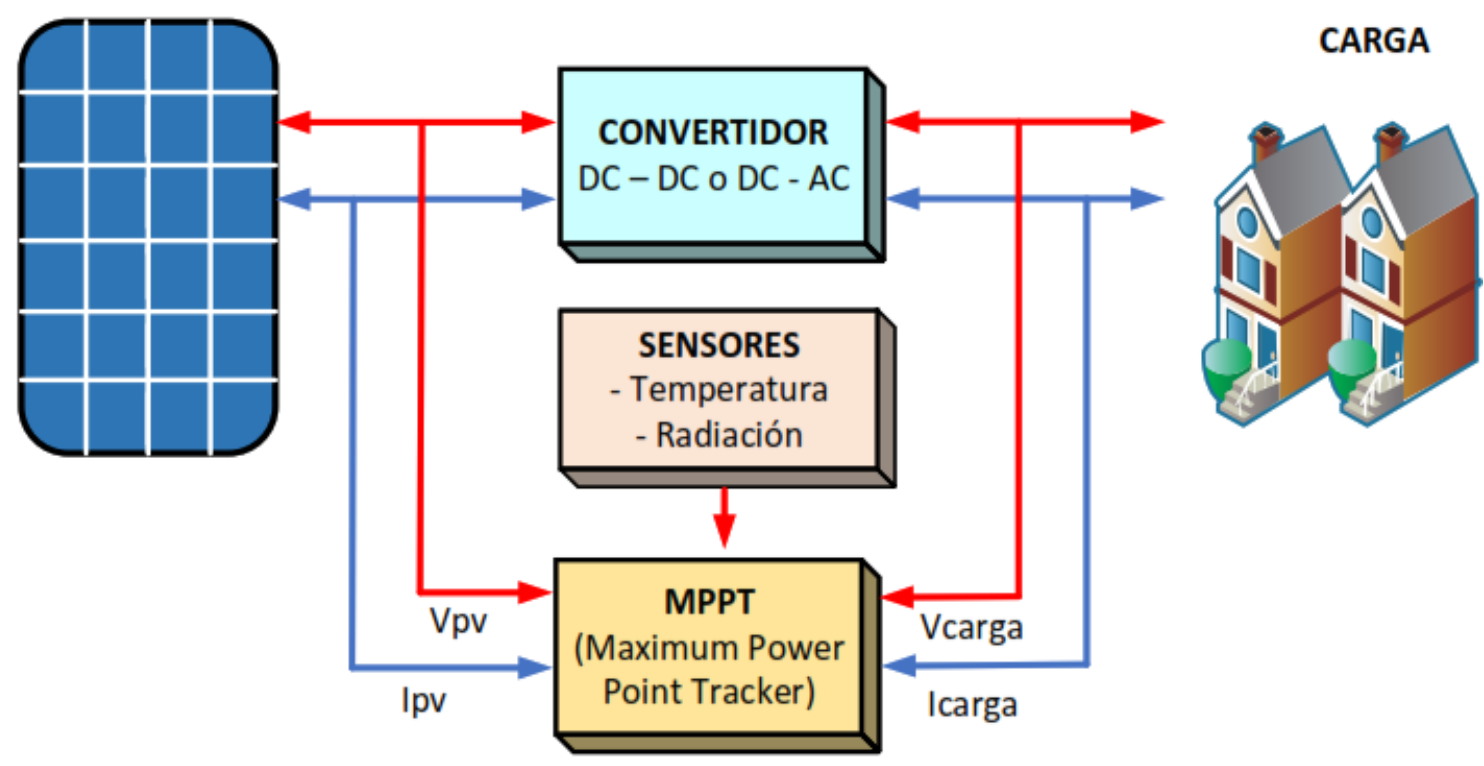

Source: own

\section{Maximal power point tracking in isolated} photovoltaic systems.

The observation and disturbance method is that the PV system controller changes the output power of the PV array using a minor disturbance in each control period to determine if the direction of the disturbance is correct. If the output power increases, the direction of the disturbance remains the same as in the last control period. But if the output power decreases, the disturbance direction must be changed to the opposite one. In this way, the actual working point of the photovoltaic array is gradually closing to the point of maximum power and is finally reaching the alternative steady state in a small range near it [6-8].

The disturbance and observation method can be easily performed and its sensor accuracy requirement is not high. But the pace of the disturbance is a constant. It will produce large fluctuations near the point of maximum power and will cause serious energy loss if the step size is large [9-14]. If the step size is small, the number of disturbances necessary to reach the point of maximum power will be greater and the time will be much longer. Therefore, we cannot consider tracking accuracy and response speed when selecting step size $[15-26]$.
3. Formulation of the Problem

Table 1: The variables of the MPPT model.

\begin{tabular}{|l|l|}
\hline Symbol & \multicolumn{1}{|c|}{ Quantity } \\
\hline $\mathrm{D}$ & Duty cycle \\
\hline $\mathrm{t}$ & Weather \\
\hline $\mathrm{I}$ & Stream \\
\hline $\mathrm{V}$ & Voltage \\
\hline $\mathrm{P}$ & Power \\
\hline $\mathrm{T}$ & Temperature \\
\hline PV & Matrix Voltage \\
\hline MPPT & Maximum Power Point Tracking \\
\hline
\end{tabular}

Source: own

\subsection{Mathematical Model}

Incremental Conductance Method Objective Function:

$$
P_{P V}=V_{P V} \cdot I_{P V}
$$




\section{Algorithm}

Entry: Run the model provided by Simulink

Departure: Clustering

Step 1: From $\mathrm{t}=0[\mathrm{~s}]$ to $\mathrm{t}=0.05[\mathrm{~s}]$ the pulses to the Boost and VSC converters are blocked.

At $\mathrm{t}=0.05[\mathrm{~s}]$ Boost and VSC converters are unlocked.

The DC link voltage is regulated to $\mathrm{Vcc}=500[\mathrm{~V}]$ Calculate \# zones $=\mathrm{P}$

When the steady state reaches $\mathrm{t}=0.25[\mathrm{~s}]$ the resulting $\mathrm{PV}$ voltage is: $\mathrm{Vdc}=250[\mathrm{~V}]$ and the output power of the array is $96[\mathrm{~kW}$, while the irradiance power is approximately $100.7[\mathrm{~kW}]$.

Step 2: At $\mathrm{t}=0.4[\mathrm{~s}]$ the MPTT is enabled, therefore the regulator begins to set the voltage by varying the duty cycle to extract the maximum power.

When $\mathrm{D}=0.454$, the maximum power of $100.4[\mathrm{~kW}]$ is obtained.

At $\mathrm{t}=0.6[\mathrm{~s}]$ The matrix voltage $\mathrm{PV}=274[\mathrm{~V}]$ (As expected in the module specifications).

From $\mathrm{t}=0.6[\mathrm{~s}]$ to $=1.1[\mathrm{~s}]$ Solar irradiance decreases from 1000 to 250, while MPPT continues to track peak power.

Step 3: At $\mathrm{t}=1.2[\mathrm{~s}]$ when the irradiance has been reduced to 250, the Duty Cycle $\mathrm{D}=0.461$, the voltage Vmean $=268[\mathrm{~V}]$ and Pmean $=24.3[\mathrm{~kW}]$.

From $\mathrm{t}=1.2[\mathrm{~s}]$ to $=2.5[\mathrm{~s}]$ Solar irradiation is restored to $1000[\mathrm{~W}]$ and the temperature increases to $50{ }^{\circ} \mathrm{C}$, when the temperature rises from $25{ }^{\circ} \mathrm{C}$ to $50{ }^{\circ} \mathrm{C}$ the output power of the set decreases from $100.7[\mathrm{~kW}]$ to $93[\mathrm{~kW}]$.

Subject to:

$$
\begin{gathered}
\frac{d P_{P V}}{d V_{P V}}=I_{P V}+V_{P V} \frac{d I_{P V}}{d V_{P V}}=0 \\
\frac{d I_{P V}}{d V_{P V}}=-\frac{I_{P V}}{V_{P V}}
\end{gathered}
$$

\section{Analysis of Results}

When the radiation values vary, the average power values vary, depending on the amount of radiation, the values used in the simulations are 400, 600, 800, 1000 giving a small disturbance at 0.1 seconds and then stabilizing at a value of $35,55,75,95$ on average as shown in the graph (Fig. 2).

The same experimentation was carried out when varying the temperature and variation in the Duty cycle was visualized due to its relationship, the values we gave at temperature for this simulation are 20, 30. 40, 50 the same ones that make the Duty Cycle vary which it begins witha value of 0.5 and at 0.4 seconds it falls depending on the value of the temperature $0.44,0.455,0.475,0.498$ and it proceeds to stabilize as shown in the graph (Fig. 3).
Figure 2: Detail of the Power-Radiation relationship.

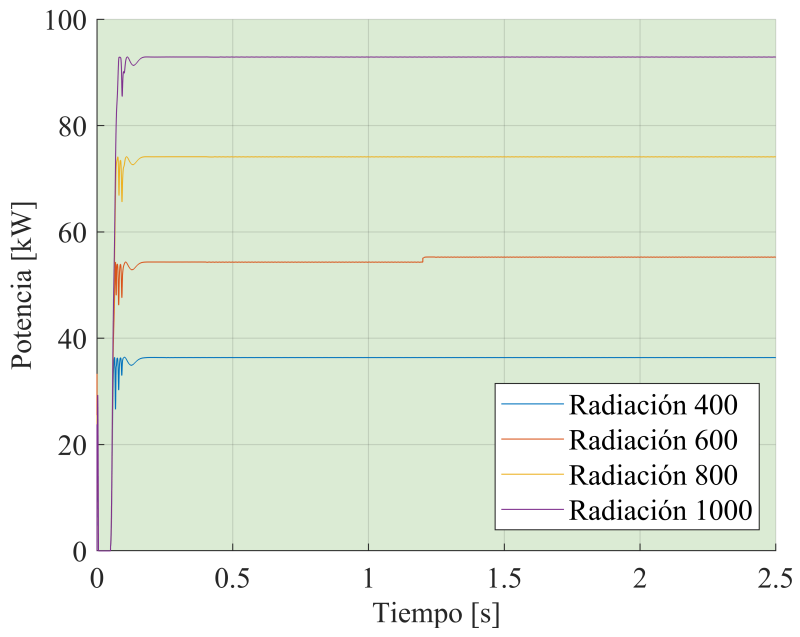

Source: own

\section{Conclusions}

We can estimate the value of the Power in KW knowing the radiation that the panel is receiving, in the graphs we can see that when we have a radiation of 400 the power is very close to the value of $40 \mathrm{KW}$, in the same way in the other experiments so that we can conclude that the expected power is the value of the Radiation divided by 10 and will give us an approximate value to the real thing. 
Figure 3: Detail of the Duty Cycle -Temperature relationship.

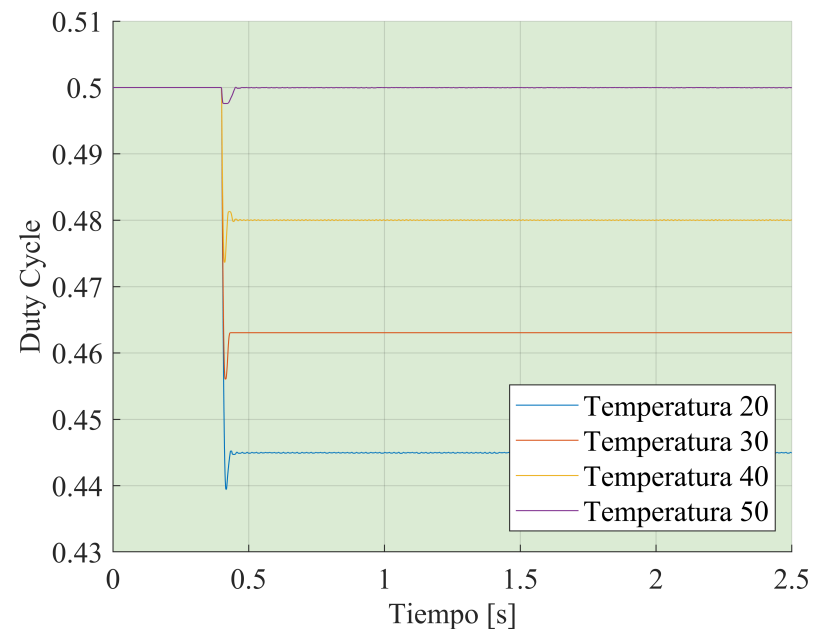

Source: own

The value of the Duty Cycle almost does not vary when the temperature varies as we have observed in the graph of Duty Cycle vs Time but it should be noted that having a value of 50 degrees the Duty Cycle has a small disturbance and remains at its value, at reducing the temperature value by 10 degrees the Duty Cycle value falls to 0.4 seconds and loses 2 hundredths of the value it was in, and this is similarly reproduced in the other simulations.

\section{References}

[1] G. R. Zhang and R. X. Xiang, "Research on the MPPT of photovoltaic cells", Energy Engineering, no. 1, pp.13-16, January 2009.

[2] C. Thueanpangthaim, P. Wongyai, K. Areerak, and K. Areerak, "The maximum power point tracking for stand-alone photovoltaic system using current based approach", International Electrical Engineering Congress (iEECON), pp. 1-4, 2017. https://doi .org/10.1109/IEECON . 2017.8075745

[3] N. A. Ahmed and M. Miyatake, "A stand-alone hybrid generation system combining solar photovoltaic and wind turbine with simple maximum power point tracking control", CES/IEEE 5th International Power Electronics and Motion Control Conference, pp. 13- 16, 2006. https://doi.org/10.1109/IPEMC . 2006.4777984

[4] J. Khanam and S. Y. Foo, "Neural Networks Technique for Maximum Power Point Tracking of
Photovoltaic Array", Conference Proceedings - IEEE SoutheastCon, pp. 1- 4, 2018. https ://doi.org/10. 1109/SECON . 2018.8479054

[5] M. J. Khan and L. Mathew, "Artificial intelligence based maximum power point tracking algorithm for photo-voltaic system under variable environmental conditions", Recent Developments in Control, Automation and Power Engineering, RDCAPE, pp. 114-119, 2017. https://doi.org/10.1109/RDCAPE. 2017.8358251

[6] S. Shi, Y. Wang and P. Jin, "Study of maximum power point tracking methods for photovoltaic power generation system", Proceedings - Chinese Automation Congress, pp. 835-840, 2013. https:// doi.org/10.1109/CAC. 2013.6775849

[7] H. Boumaaraf, A. Talha and O. Bouhali, "Maximum power point tracking using neural networks control for grid-connected photovoltaic system", International Conference on Power Engineering, Energy and Electrical Drives, pp. 593-597, 2013. https ://doi.org/10.1109/PowerEng. 2013. 6635675

[8] C. Huang, L. Wang, H. Long, X. Luo and J. H. Wang, "A hybrid global maximum power point tracking method for photovoltaic arrays under partial shading conditions", Optik, vol. 180, pp. 665-674, 2019. https://doi.org/10.1016/j.ijleo.2018.11.158

[9] S. K. Sahoo, M. Balamurugan, S. Anurag, R. Kumar and V. Priya, "Maximum power point tracking for PV panels using ant colony optimization", Innovations in Power and Advanced Computing Technologies, i-PACT, pp. 1-4, 2017. https://doi. org/10.1109/IPACT . 2017.8245004

[10] S. S. Mohammed, D. Devaraj and T. P. Ahamed, "Maximum power point tracking system for stand alone solar PV power system using Adaptive Neuro-Fuzzy Inference System", Biennial International Conference on Power and Energy Systems: Towards Sustainable Energy, PESTSE, pp. 1-4, 2016. https://doi.org/10.1109/PESTSE. 2016.7516536

[11] T. Esram and P. L. Chapman, "Comparison of photovoltaic array maximum power point tracking techniques", IEEE Trans. Energy Convers., vol. 22, no. 2, pp. 439-449, 2007. https://doi.org/10. 1109/TEC. 2006.874230

[12] K. Ishaque and Z. Salam, "A review of maximum power point tracking techniques of $\mathrm{PV}$ system for uniform insolation and partial shading condition", 
Renewable and Sustainable Energy Reviews, vol. 19 pp. 475-488, 2013. https://doi.org/10.1016/j. rser. 2012.11 .032

[13] L. Liu, X. Meng, and C. Liu. "A review of maximum power point tracking methods of $\mathrm{PV}$ power system at uniform and partial shading", Renewable and Sustainable Energy Reviews, vol. 53, pp. 1500-1507, 2016. https://doi.org/10.1016/j.rser.2015.09. 065

[14] A. Kouchaki, H. Iman-Eini, and B. Asaei, "A new maximum power point tracking strategy for PV arrays under uniform and non-uniform insolation conditions", Solar Energy, vol. 91, pp.221-232, 2013. https : //doi.org/10.1016/j.solener. 2013. 01.009

[15] R. C. Pilawa-Podgurski and D. J. Perreault, "Submodule integrated distributed maximum power point tracking for solar photovoltaic applications", IEEE Transactions on Power Electronics, vol. 28, no. 6, pp. 2957-2967, 2013. https://doi.org/10.1109/ TPEL . 2012 . 2220861

[16] C. Woei-Luen, and C. Tsai. "Optimal balancing control for tracking theoretical global MPP of series PV modules subject to partial shading", IEEE Transactions on Industrial Electronics, vol. 62, no. 8, pp. 4837-4848, 2015. https://doi.org/10.1109/ TIE. 2015.2400414

[17] K. Ishaque, Z. Salam, M. Amjad and S. Mekhilef, "An improved Particle Swarm Optimization (PSO)-based MPPT for PV with reduced steady-state oscillation", IEEE Transactions on Power Electronics, vol. 27, no. 8, pp. 3627-3638, 2012. https://doi.org/10.1109/TPEL . 2012.2185713

[18] E. Karatepe and T. Hiyama, "Performance enhancement of photovoltaic array through string and central based MPPT system under non-uniform irradiance conditions", Energy Conversion and Management, vol. 62, pp. 131-140, 2012. https:// doi.org/10.1016/j.enconman.2012.03.028

[19] S. Daraban, D. Petreus and C. Morel, "A novel global MPPT based on genetic algorithms for photovoltaic systems under the influence of partial shading", IECON- 39th
Annual Conference of the IEEE Industrial Electronics Society, pp. 1490-1495, 2013. https://doi .org/10.1109/IECON . 2013.6699353

[20] K. Sundareswaran, S. Peddapati and S. Palani, "MPPT of PV systems under partial shaded conditions through a colony of flashing fireflies", IEEE Transactions on Energy Conversion, vol. 29, no. 2, pp. 463-472, 2014. https://doi.org/10. 1109/TEC. 2014.2298237

[21] K. Sundareswarm, P. Sankar, P. S. Nayak, S. P. Simon, and S. Palani, "Enhanced energy output from a PV system under partial shaded conditions through artificial bee colony", IEEE Transactions on Sustainable Energy, vol. 6, no. 1, pp. 198-209, 2015. https://doi.org/10.1109/TSTE. 2014.2363521

[22] S. Lyden, and M. E. Haque, "A simulated annealing global maximum power point tracking approach for PV modules under partial shading conditions", IEEE Transactions on Power Electronics, vol. 31, no. 6, pp. 4171-4181, 2016. https://doi.org/10.1109/TPEL. 2015.2468592

[23] H. Patel and V. Agarwal, "Maximum power point tracking scheme for PV systems operating under partially shaded conditions", IEEE Transactions on Industrial Electronics, vol. 55, no. 4, pp. 1689-1698, 2008. https://doi.org/10.1109/TIE.2008.917118

[24] J. Qi, Y. Zhang, and Y. Chen, "Modeling and maximum power point tracking (MPPT) method for PV array under partial shade conditions", Renewable Energy, vol. 66, pp. 337-345, 2014. https://doi.org/10.1016/j.renene.2013.12.018

[25] E. Koutroulis and F. Blaabjerg, "A new technique for tracking the global maximum power point of $\mathrm{PV}$ arrays operating under partial-shading conditions", IEEE Journal of Photovoltaics, vol. 2, no. 2, pp. 184-190, 2012. https://doi.org/10. 1109/JPHOTOV . 2012. 2183578

[26] K. S. Tey and S. Mekhilef, "Modified incremental conductance algorithm for photovoltaic system under partial shading conditions and load variation", IEEE Transactions on Industrial Electronics, vol. 61, no. 10, pp. 5384-5392, 2014. https://doi.org/10. 1109/TIE. 2014. 2304921 